\title{
New records of feather mites (Sarcoptiformes: Proctophyllodidae) on tanagers (Passeriformes: Thraupidae) from Brazil
}

\author{
Fabio A. Hernandes $=$ \\ Departamento de Ecologia e Zoologia, CCB/ECZ, Trindade, Universidade Federal de Santa Catarina (UFSC), Florianópolis, SC, Brazil. \\ 麦=Corresponding author: abakashi@gmail.com
}

Edited by: Ricardo Bassini (Guest Editor)

Received: October 20, 2021. Accepted: October 25, 2021. Published: December 07, 2021.

Abstract. Herein, three feather mite species (Analgoidea: Proctophyllodidae) are reported from tanagers (Passeriformes: Thraupidae) in Brazil: Proctophyllodes thraupis Atyeo \& Braasch, 1966 on Thraupis ornata (Sparrman, 1789), Thraupis palmarum (Wied, 1821), and Stilpnia peruviana (Desmarest, 1806); Amerodectes thraupicola (Černý, 1974) and Amerodectes bilineatus (Berla, 1958) on T. ornata. Proctophyllodes thraupis is herein reported for the first time on the hosts mentioned above. Amerodectes thraupicola is reported in synoxenism with A. bilineatus on the same bird specimen of $T$. ornata, a new host for both mites. Despite being described from a Cardinalidae (Passeriformes) host, this latter mite species was subsequently recovered only from tanagers, which reinforces the suggestion that non-thraupid hosts might be accidental records.

Keywords: Acari, new records, plumicolous mites.

Feather mites (Sarcoptiformes: Astigmata) are permanent, obligate ectosymbionts (Doña et al. 2019) associated with all major groups of birds (Gaud \& Atyeo 1996). About 2600 species have been described worldwide (Mironov 2016; Dabert et al. 2021). Gaud \& Atyeo (1996) classified the feather mites in three superfamilies of Astigmata (Analgoidea Trouessart \& Mégnin, 1884, Freyanoidea Dubinin, 1953, and Pterolichoidea Trouessart \& Mégnin, 1884), but other authors have demonstrated that Freyanoidea is a taxon included within the Pterolichoidea (OConnor 1982; Ehrnsberger et al. 2001; Klimov \& OConnor 2008) and therefore does not deserve a superfamilial status.

Thraupidae Cabanis, 1947 (Passeriformes: Oscines) currently includes 386 species exclusively in the Neotropical region (Gill et al. 2021; Burns et al. 2016) and is one of the most diverse passerine families of Brazil, with 156 species (Pacheco et al. 2021). Feather mites were reported in Brazil from 32 tanager species (Thraupidae), mostly belonging to the families Proctophyllodidae Trouessart \& Mégnin, 1884, Trouessartiidae Gaud, 1957, Analgidae Trouessart \& Mégnin, 1884, Psoroptoididae Gaud, 1958, and Dermationidae Fain, 1965. From 14 of these birds, 13 mite species have been nominally described or reported in Brazil (Valim et al. 2011; Enout et al. 2012; Hernandes 2014; Hernandes \& Valim 2014; Daud et al. 2015; Silva et al. 2015; Hernandes et al. 2016; Hernandes \& Flechtmann 2020).

Herein, three new records of feather mites are presented from tanagers (Thraupidae) in Brazil. The feather mites were collected either from birds found dead or captured for banding and released afterward. The mites were removed from the feathers under a dissecting microscope with a fine brush or a teaser. Mite specimens were mounted in glass slides using Hoyer's medium. Vouchers are deposited at the mite collection of the Department of Ecology and Zoology of the Universidade Federal de Santa Catarina (ECZ - UFSC).

Analgoidea Trouessart \& Mégnin, 1884

Proctophyllodidae Trouessart \& Mégnin, 1884

Proctophyllodinae Trouessart \& Mégnin, 1884

Proctophyllodes thraupis Atyeo \& Braasch, 1966 (Figs. A-C)

Material examined: 2 males; ex. Thraupis ornata (Sparrman, 1789); July 2021; Florianópolis, Santa Catarina State, Brazil; $27^{\circ} 36^{\prime} \mathrm{S}, 48^{\circ} 31^{\prime} \mathrm{W}$; F.A. Hernandes col. 3 males and 3 females; ex. Thraupis palmarum
(Wied, 1821); December 2009; Pedreira; São Paulo State; Brazil; $22^{\circ} 44^{\prime} \mathrm{S}, 46^{\circ} 54^{\prime} \mathrm{W}$; David Vilas-Boas Filho col. 2 males, 1 female, and 4 nymphs; ex. Stilpnia peruviana (Desmarest, 1806); January 2012; Lagoa do Parado, Guaratuba, Paraná State, Brazil; $25^{\circ} 49^{\prime} \mathrm{S}, 48^{\circ} 37^{\prime} \mathrm{W}$; Bianca L. Reinert col.

Remarks: This species was described from Thraupis abbas (Deppe, 1830) (type host) from Mexico and Chlorophanes spiza (Linnaeus, 1758) (Thraupidae) from Belize and Mexico (Atyeo \& Braasch 1966). Mironov et al. (2017) reported this species on Tangara icterocephala (Bonaparte, 1851) from Costa Rica, and Hernandes \& Flechtmann (2020) on Thraupis sayaca (Linnaeus, 1766) from Brazil. It is reported for the first time on T. ornata, T. palmarum, and S. peruviana.

In the original publication, this species was also reported on hosts of other families, such as Chlorospingus flavopectus ophthalmicus (Du Bus de Gisignies, 1847) (Passerellidae), Euphonia affinis (Lesson, 1842) (as Tanagra affinis) from Mexico, Euphonia hirundinacea Bonaparte, 1838 (as Tanagra lauta) from Belize, and Euphonia musica (Gmelin, 1789) (as Tanagra musica) (Fringillidae) from Mexico. These records from non-thraupid hosts are suspected to be accidental contaminations (Mironov et al. 2017).

\section{Pterodectinae Park \& Atyeo, 1971}

\section{Amerodectes thraupicola (Černý, 1974) (Figs. D-F)}

Material examined: 4 males and 4 females; ex. T. ornata; July 2021; Florianópolis, Santa Catarina State, Brazil; $27^{\circ} 36^{\prime}$ S, $48^{\circ} 31^{\prime} W ;$ F.A. Hernandes col.

Remarks: This species was described from Thraupis episcopus (Linnaeus, 1766) in Suriname (Černý 1974), and later reported on the same host in Brazil, in addition to Thraupis cyanoptera (Vieillot, 1817), T. palmarum, and T. sayaca (Linnaeus, 1766) from Brazil (Valim \& Hernandes 2010). On two hosts - T. episcopus and T. sayaca - this species was reported in synoxenism (i.e., coinhabiting the same host specimen) with Amerodectes bilineatus (Berla, 1959) (Valim \& Hernandes 2010). Thraupis ornata is a new host for this mite species and is the third host on which $A$. thraupicola is reported in synoxenism with $A$. bilineatus.

The females of $A$. thraupicola are remarkable in having an extremely elongated primary duct of spermatheca (about $600 \mu \mathrm{m}$ long), whereas 


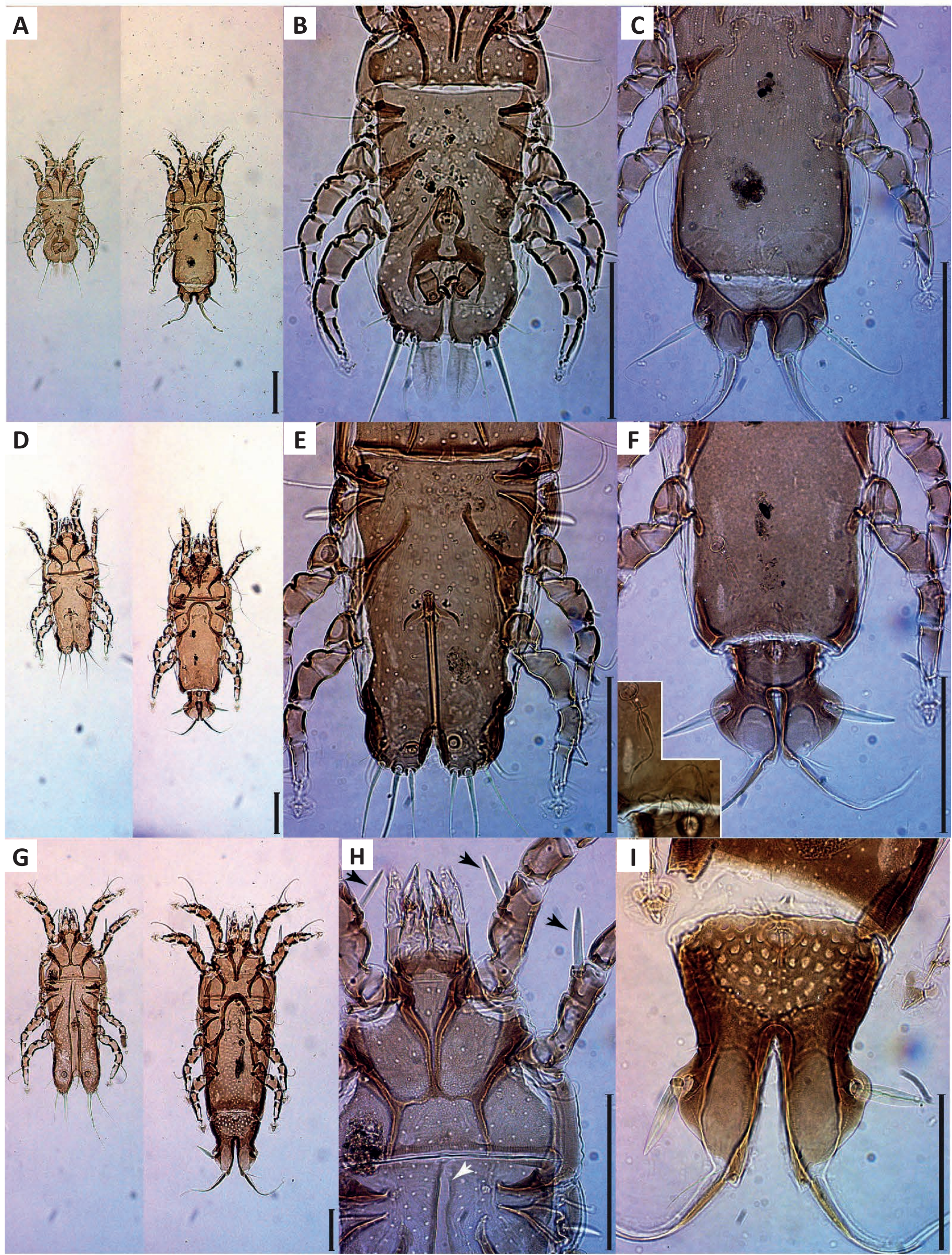

Figure 1. Feather mites of the family Proctophyllodidae Trouessart \& Mégnin, 1884, recorded on tanagers (Thraupidae) in Brazil: Proctophyllodes thraupis Atyeo \& Braasch, 1966, male (left) and female (right) (A), ventral view of idiosoma of male (B), and female (C); Amerodectes thraupicola (Černý, 1974), male (left) and female (right) (D), ventral view of idiosoma of male (E), and female (F; detail of spermatheca with elongated primary duct); Amerodectes bilineatus (Berla, 1958), male (left) and female (right) $(G)$, dorsal view of propodosoma of male $(\mathrm{H}$; black arrows = enlarged setae $c G$ on genua I and II; white arrow = dorsal groove on hysteronotal shield of male), and dorsal view of female lobar region (I). Scale bars: $=100 \mathrm{~mm}$. 
in other species, it is commonly around $100-150 \mu \mathrm{m}$ or less.

\section{Amerodectes bilineatus (Berla, 1958) (Figs. G-I)}

Material examined: 4 males and 4 females; ex. T. ornata; July 2021; Florianópolis, Santa Catarina State, Brazil; $27^{\circ} 36^{\prime} S$, $48^{\circ} 31^{\prime}$ W; F.A. Hernandes col.

Remarks: This species was described from a cardinalid, Caryothraustes canadensis (Linnaeus, 1766) (Passeriformes: Cardinalidae), but was subsequently reported only on tanagers (Thraupidae): T. episcopus, T. sayaca (see Valim \& Hernandes 2010), and T. palmarum (see Enout et al. 2012). Thraupis ornata is a new host for $A$. bilineatus, and the finding of this mite on another tanager reinforces the suspicion that the original host probably resulted from accidental contamination (Valim \& Hernandes 2010).

This species is very similar to Amerodectes storkani (Černý, 1974) described from Ramphocelus carbo (Pallas, 1764) and also reported on Ramphocelus bresilia (Linnaeus, 1766) in having remarkably enlarged setae $c G$ on genua I and II (Fig. $1 \mathrm{H}$, black arrows) in both males and females. In males of both these species, there is a dorsal median groove on the hysteronotal shield, which in $A$. bilineatus reaches the anterior margin of this shield (Fig. $1 \mathrm{H}$, white arrow), whereas in $A$. storkani it reaches slightly anterior to that level - approximately at the level of seta c3 (Valim \& Hernandes 2010).

Since the publication of the first checklist of feather mites from Brazil (Valim et al. 2011), when 185 nominal feather mite species were accounted for, substantial advances have been made (e.g., Pedroso \& Hernandes 2016; Hernandes 2020). About 320 nominal species are currently recorded from Brazil, but that number is still dwarfed by the estimated diversity of 900-5300 species associated with birds in that country (Valim et al. 2011).

\section{Acknowledgments}

I am indebted to the late Dr. Bianca L. Reinert (1966-2018) for her efforts in studying and preserving the biodiversity in Paraná State; Bianca collected the feather mites from the Black-backed Tanager (Stilpnia peruviana) reported herein, among many other feather mites. I am also very thankful to David Vilas Boas Filho, for collecting and sending me the feather mites from Thraupis palmarum. The author receives a productivity research fellowship from CNPq (304479/20195).

\section{References}

Atyeo, W. T.; Braasch, N. L. (1966) The feather mite genus Proctophyllodes (Sarcoptiformes: Proctophyllodidae). Bulletin of the University of Nebraska State Museum, 5: 1-354.

Burns, K. J.; Unitt, P.; Mason, N. A. (2016) A genus-level classification of the family Thraupidae (Class Aves: Order Passeriformes). Zootaxa, 4088(3): 329-354. doi: 10.11646/zootaxa.4088.3.2

Černý, V. (1974) Parasitic mites of Surinam. XXXI. New species of Proctophyllodidae (Sarcoptiformes, Analgoidea). Folia Parasitologica, 21: 349-361.

Dabert, J.; Mironov, S.V.; Dabert, M. (2021) The explosive radiation, intense host-shifts, and long-term failure to diverge in the evolutionary history of the feather mite genus Analges (Acariformes: Analgidae) from the European passerines - a molecular approach. Zoological Journal of the Linnean Society, 193: 1-22. doi: 10.1093/ zoolinnean/zlab057

Daud, R. D.; Hernandes, F. A.; Bispo, A. A. (2015) Wing Feather Mites (Acari: Astigmata) on some Passeriformes (Aves) from State of Paraná, Brazil. Revista Brasileira de Ornitologia, 23: 336-340.

Doña, J.; Proctor, H.; Serrano, D.; Johnson, K. P.; Oploo, A. O.; HuguetTapia, J. C.; Ascunce, M. S.; Jovani, R. (2019) Feather mites play a role in cleaning host feathers: New insights from DNA metabarcoding and microscopy. Molecular Ecology, 28(2): 203-218. doi: 10.1111/ mec.14581

Enout, A. M. J.; Lobato, D. N. C.; Diniz, F. C.; Antonini, Y. (2012) Chewing lice (Insecta, Phthiraptera) and feather mites (Acari, Astigmata) associated with birds of the Cerrado in central Brazil. Parasitology Research, 111: 1731-1742. doi: 10.1007/s00436-012-3016-5

Ehrnsberger, R.; Mironov, S. V.; Dabert, J. (2001) A preliminary analysis of phylogenetic relationships of the feather mite family Freyanidae Dubinin, 1953 (Acari: Astigmata). Biological Bulletin of Adam Mickiewicz University, Zoology, 38(2): 181-201.

Gaud, J.; Atyeo, W. T. (1996) Feather mites of the World (Acarina, Astigmata): the supraspecific taxa. Annales du Musée Royale de I'Afrique Centrale, Sciences Zoologiques, 277, 1-193 (Pt. 1, text), 1-436 (Pt. 2, illustrations).

Gill, F.; Donsker, D.; Rasmussen, P. (2021) IOC World Bird List (v 11.1). http://www.worldbirdnames.org. Access on 15.x. 2021.

Hernandes, F. A. (2014) Five new species of the feather mite genus Trouessartia Canestrini from South America (Acari: Trouessartiidae). Zootaxa, 3856: 50-72. doi: 10.11646/zootaxa.3856.1.2

Hernandes, F. A. (2020) A review of the feather mite family Gabuciniidae Gaud \& Atyeo (Acariformes: Astigmata: Pterolichoidea) of Brazil, with descriptions of eleven new species. Zootaxa, 4747 (1): 1-53. doi: 10.11646/zootaxa.4747.1.1

Hernandes, F. A.; Flechtmann, C. H. W. (2020) New records of feather mites (Acariformes: Analgoidea, Pterolichoidea) in Piracicaba, SP, Brazil. Entomological Communications, 2: 1-3, ec02006. doi: 10.37486/2675-1305.ec02006

Hernandes, F. A.; Pedroso, L. G. A.; Oniki-Willis, Y. (2016) Five new feather mites of the subfamily Pterodectinae (Acariformes: Astigmata: Proctophyllodidae) from passerines and hummingbirds (Aves) of Brazil. Zootaxa, 4161(3): 301-328. doi: 10.11646/zootaxa.4161.3.1

Hernandes, F.A.; Valim, M. P. (2014) On the identity of two species of Proctophyllodidae (Acari: Astigmata: Analgoidea) described by Herbert F. Berla in Brazil, with a description of Lamellodectes gen. nov. and a new species. Zootaxa, 3794(1): 179-200. doi: 10.11646/ zootaxa.3794.1.8

Klimov, P.; OConnor, B. M. (2008) Origin and higher-level relationships of psoroptidian mites (Acari: Astigmata: Psoroptidia): Evidence from three nuclear genes. Molecular Phylogenetics and Evolution, 47(3): 1135-1156. doi: 10.1016/j.ympev.2007.12.025

Mironov, S. V. (2016) Chapter V. Host-parasite relations of mites of the parvorder Psoroptidia (Acariformes: Astigmata) with birds. In: Galaktionov K.V. (Ed.), Coevolution of Parasites and Hosts. Saint Petersburg: Zoological Institute of the Russian Academy of Sciences, pp. 264-348. [In Russian]

Mironov, S. V.; Literak, I.; Sychra, O.; Capek, M. (2017) Feather mites of the subfamily Proctophyllodinae (Acari: Proctophyllodidae) from passerines (Aves: Passeriformes) in Costa Rica. Zootaxa, 4297(1): 1-105. doi: 10.11646/zootaxa.4297.1.1

OConnor, B. M. (1982) Astigmata. In: S.B. Parker (Ed). Synopsis and Classification of Living Organisms. Vol. 2. New York: McGraw-Hill, pp. 146-169.

Pacheco, J. F.; Silveira, L. F.; Aleixo, A.; Agne, C. E.; Bencke, G. A.; Bravo, G. A.; Brito, G. R. R.; Cohn-Haft, M.; Maurício, G. N.; Naka, L. N.; Olmos, F.; Posso, S.; Lees, A. C.; Figueiredo, L. F. A.; Carrano, E.; Guedes, R. C.; Cesari, E.; Franz, I.; Schunck, F.; \& Piacentini, V. Q. (2021) Annotated checklist of the birds of Brazil by the Brazilian Ornithological Records Committee - second edition. Ornithology Research, 29(2): 1-123. doi: 10.1007/s43388-021-00058-x

Pedroso, L. G. A.; Hernandes, F. A. (2016) New records of feather mites (Acariformes: Astigmata) from nonpasserine birds (Aves) in Brazil. Checklist, 12(6): 1-25. doi: 10.15560/12.6.2000

Silva, H. M.; Hernandes, F. A.; Pichorim, M. (2015) Feather mites (Acari, Astigmata) associated with birds in an Atlantic Forest fragment in Northeastern Brazil. Brazilian Journal of Biology, 75(3): 726-735. doi: 10.1590/1519-6984.23313

Valim, M. P.; Hernandes, F. A. (2010) A systematic review of feather mites of the Pterodectes generic complex (Acari: Proctophyllodidae) with redescriptions of species described by Vladimir Černý. Acarina 18(1): 3-35.

Valim, M. P.; Hernandes, F. A.; Proctor, H. C. (2011) Feather mites of Brazil (Acari: Astigmata: Analgoidea, Freyanoidea and 
Pterolichoidea). International Journal of Acarology, 37(4): 293-324. doi: 10.1080/01647954.2010.519719 